\title{
The digestion process of the sugar alcohol isomalt in the intestinal tract of the pig
}

\author{
1. Studies with administration of isomalt in the feed \\ BY E. J. VAN WEERDEN AND J. HUISMAN \\ TNO-Institute of Animal Nutrition and Physiology (ILOB), PO Box 15,6700 AA Wageningen, \\ The Netherlands
}

(Received 12 September 1991-Accepted 25 March 1992)

\begin{abstract}
In a study with twelve pigs of $60-70 \mathrm{~kg}$ live weight provided with a re-entrant cannula at the end of the ileum, and twelve intact, non-cannulated pigs, the fate of dietary doses of 100 and $200 \mathrm{~g}$ isomalt/ $\mathrm{kg}$ during gastrointestinal passage was examined. From sugar analyses in ileal chyme it was calculated that 0.43 and 0.30 of the isomalt consumed was digested in the small intestine with the 100 and $200 \mathrm{~g} / \mathrm{kg}$ doses of isomalt respectively. From findings on ileal energy digestibility it was calculated that, because of a secondary effect of isomalt on the digestion of the basal diet, isomalt digestibility in the small intestine was distinctly lower. In faeces no sugars were found, so faecal digestibility of isomalt was 1.00 for both doses. The bacterial fermentation in the large intestine of the isomalt not digested in the small intestine caused an increase in the faecal excretion of nitrogen and energy. This increased faecal excretion was hardly (nitrogen) or not (energy) compensated by a decreased urinary excretion.
\end{abstract}

Isomalt: Sugar digestion: Disaccharide alcohols: Pig

Isomalt is an approximately equimolar mixture of the two stereoisomeric disaccharide alcohols with $\alpha$-glycoside bonds, $\alpha$-D-glucopyranosyl-1,1-D-mannitol (GPM) and $\alpha$-Dglucopyranosyl-1,6-D-sorbitol (GPS). The trade name is Palatinit ${ }^{\mathrm{R}}$; this product contains approximately $50 \mathrm{~g}$ water of crystallization $/ \mathrm{kg}$ (GPM.2aq). Isomalt is a sweet-tasting product that can be used as a bulk sweetener instead of sugar in human foods (Schiweck, 1980). Musch et al. (1973), Grupp \& Siebert (1978), Nilsson \& Jägerstad (1987) and Heymann (1991) showed in studies in vitro with rat, human and pig mucosa that hydrolysis of both disaccharide components of isomalt by intestinal $\alpha$-glycosidases is very slow. The disaccharide alcohols are not absorbed as such (Grupp \& Siebert, 1978). These observations indicate that only a part of the ingested isomalt will be hydrolysed to the monosaccharide components glucose, mannitol and sorbitol in the small intestine. The other part will reach the large intestine where bacterial degradation of isomalt and its components will take place. This fermentation process is coupled with a considerable loss of energy, estimated by Van Es $(1982,1987)$ at $40-53 \%$ and by Just et al. (1983) at about $50 \%$. However, results of studies of Close et al. $(1989,1990)$ suggest that this loss may be considerably smaller.

The content of useful energy of isomalt is, therefore, dependent on the ratio between the part hydrolysed and absorbed in the small intestine:the part fermented in the large intestine. Because of the well-known difficulties of collecting reliable data on the extent of the digestion process in the different parts of the gastrointestinal tract of man, a model study with pigs was carried out. According to Graham \& Aman (1987) the pig is in size, diet and gastrointestinal physiology most similar to man.

Pigs fitted with a cannula at the end of the ileum and normal intact animals were used 
in a digestion study. In the present study the passage of sugar components at the end of the ileum and at the end of the gastrointestinal tract was measured by analysing ileal chyme and faeces respectively, and comparing these quantities with the amounts consumed. This means in fact that the recovery rate of the components was measured.

In the first experiment dietary levels of 100 and $200 \mathrm{~g}$ isomalt $/ \mathrm{kg}$ were studied. In the second experiment intake levels of isomalt were lower, i.e. 50 and $100 \mathrm{~g} / \mathrm{kg}$, and in order to simulate more closely the pattern of sugar consumption in man, sugar was also given between meals as a kind of 'sweet'. The results of the first experiment are presented.

\section{MATERIAL AND METHODS}

\section{Treatments and diets}

Three treatment groups were involved; each treatment comprised four cannulated and four non-cannulated pigs. The pigs were fed on a diet comprising $(\mathrm{g} / \mathrm{kg})$ basal ingredients $(800)$ and sugars (200). Diet 1 included $200 \mathrm{~g}$ sucrose $/ \mathrm{kg}$, diet 2 contained $100 \mathrm{~g}$ sucrose and $100 \mathrm{~g}$ isomalt $/ \mathrm{kg}$, and diet 3 contained $200 \mathrm{~g}$ isomalt $/ \mathrm{kg}$. The composition of the basal diet is shown in Table 1. The analysed composition of diets and sugars is presented in Table 2. The pigs were fed the diets as a wet mixture of $800 \mathrm{~g}$ feed $+1600 \mathrm{~g}$ water twice daily at 08.00 and 20.00 hours. No additional water was administered.

\section{Animals}

Twelve cannulated and twelve non-cannulated castrated male pigs (Dutch Landrace $\times$ Large White) were involved. The cannulated pigs were surgically fitted with an ileocaecal re-entrant cannula according to the procedure described by Easter \& Tanksley (1973). After surgery the pigs were allowed to recover for a period of 4 weeks. Thereafter, an adaptation period of $9 \mathrm{~d}$ was included during which the experimental diets were fed. Next the test periods were started. In a preceding pilot experiment it was found that, judged by the colour and consistency of the faeces, pigs adapt to feeding a diet with $200 \mathrm{~g}$ isomalt $/ \mathrm{kg}$ after approximately $4 \mathrm{~d}$. The pigs were housed individually in metabolism cages that allowed separate quantitative collection of urine and faeces and quantitative collection of ileal digesta. In the experimental period the live weight of the pigs ranged between 60 and $70 \mathrm{~kg}$.

\section{Collection of ileal digesta and faeces}

The storage conditions of ileal digesta and faeces were tested before the experiment started.

For the determination of rate of passage the digesta from the distal ileum were collected quantitatively over $5 \mathrm{~d}, 12 \mathrm{~h}$ daily (from 08.00 to 20.00 hours). The ileal digesta were collected in ice, weighed each hour and then immediately stored at $-20^{\circ}$. During the quantitative collection of ileal digesta an isotonic physiological salt solution $(9 \mathrm{~g} \mathrm{NaCl} / \mathrm{l})$ was infused into the caecum via the distal cannula (approximately $80 \mathrm{ml} / \mathrm{h}$ ).

Faeces were collected in the non-cannulated pigs quantitatively over five consecutive days of $24 \mathrm{~h}$. Each day from 08.00 to 24.00 hours the faeces were collected each $4 \mathrm{~h}$. The faeces excreted during the night $(24.00-08.00$ hours) were collected at 08.00 hours. After collection faeces were immediately stored at $-20^{\circ}$. Preservative solution $(1 \mathrm{ml}$; phenol-ethyl alcohol $(50: 50, \mathrm{v} / \mathrm{v}))$ was added to each $500 \mathrm{ml}$ digesta and to each $500 \mathrm{~g}$ faeces respectively. At the termination of the experiment the digesta and faeces were homogenized and samples were freeze-dried.

For the determination of osmotic pressure, ileal digesta were collected in ice on $1 \mathrm{~d}$ from 10.00 to 12.00 hours and from 14.00 to 16.00 hours. Ileal digesta were immediately filtered under pressure following collection, no preservative was added. The osmotic pressure was determined in the supernatant fraction. 
Table 1. Composition of the basal diet $(\mathrm{g} / \mathrm{kg}$ diet)

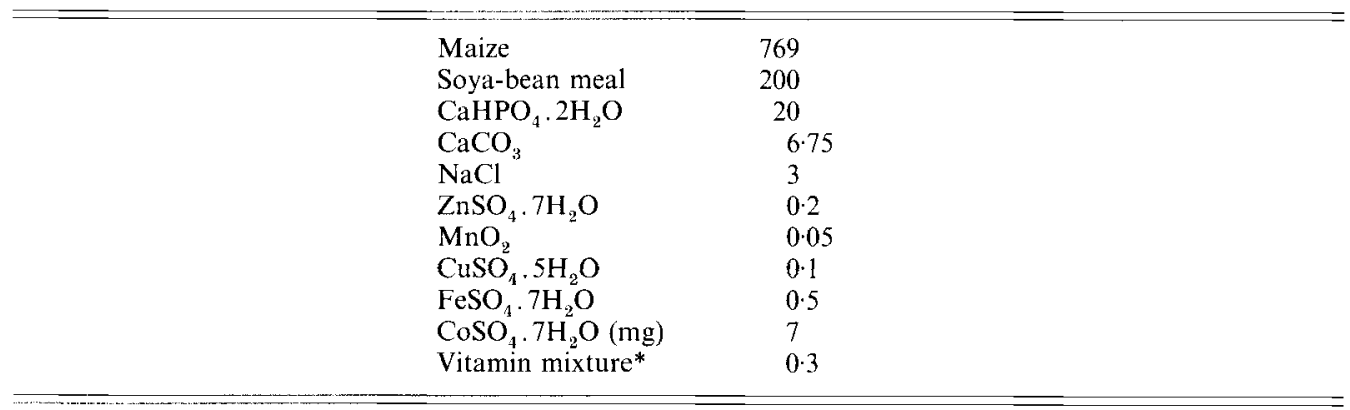

* Contributed the following nutrients $(\mathrm{mg} / \mathrm{kg}$ diet): retinol $2 \cdot 2$, cholecalciferol $38 \mu \mathrm{g}$, DL- $\alpha$-tocopherol 35 , menadione $3 \cdot 75$, riboflavin $7 \cdot 5$, nicotinic acid 37.5 , D-pantothenic acid 19 , choline chloride 120 , cyanocobalamin $45 \mu \mathrm{g}, \mathrm{KI} 1$.

Table 2. Analysed composition of the diets and the sugars $(\mathrm{g} / \mathrm{kg})$

\begin{tabular}{|c|c|c|c|c|c|}
\hline & $\begin{array}{c}\text { Diet } 1 \\
(200 \mathrm{~g} \\
\text { sucrose } / \mathrm{kg})\end{array}$ & $\begin{array}{c}\text { Diet } 2 \\
(100 \mathrm{~g} \\
\text { sucrose } \\
+100 \mathrm{~g} \\
\text { isomalt } / \mathrm{kg})\end{array}$ & $\begin{array}{c}\text { Diet } 3 \\
(200 \mathrm{~g} \\
\text { isomalt } / \mathrm{kg})\end{array}$ & Isomalt & Sucrose \\
\hline Dry matter & 916 & 909 & 902 & $989 \dagger$ & 1000 \\
\hline Ash & 43 & 43 & 44 & nd & nd \\
\hline Crude protein $(\mathrm{N} \times 6.25)$ & 126 & 130 & 127 & nd & nd \\
\hline Crude fat & 32 & 34 & 33 & nd & nd \\
\hline N-free extract (NFE) & 488 & 464 & 470 & nd & nd \\
\hline $\begin{array}{l}\text { Gross energy } \\
\text { (calculated; } \mathrm{MJ} / \mathrm{kg} \text { ) }\end{array}$ & $16 \cdot 4$ & $16 \cdot 4$ & $16 \cdot 3$ & $16 \cdot 1$ & $16 \cdot 7$ \\
\hline GPM.2aq & nd & 57 & 108 & 536 & nd \\
\hline GPS & nd & 47 & 89 & 447 & nd \\
\hline Mannitol & nd & $<\mathrm{D}$ & $<\mathrm{D}$ & $<\mathrm{D}$ & nd \\
\hline Sorbitol & nd & $<\mathrm{D}$ & $<\mathrm{D}$ & $<\mathrm{D}$ & nd \\
\hline Sucrose & $222 *$ & $116^{*}$ & 13 & nd & $>990$ \\
\hline Glucose & $2 \cdot 5$ & 3.5 & $3 \cdot 0$ & nd & nd \\
\hline Fructose & $2 \cdot 0$ & $3 \cdot 0$ & $2 \cdot 5$ & nd & nd \\
\hline
\end{tabular}

nd, Not determined; < D, below detection level (1 g/kg); GPM.2aq, $\alpha$-D-glucopyranosyl-1,1-D-mannitol; GPS, $\alpha$-D-glucopyranosyl-1,6-D-sorbitol.

* Including $13 \mathrm{~g} / \mathrm{kg}$ sucrose originating from the basal ingredients.

$\dagger$ The dry matter includes 2 molecules of water of crystalization in GPM. 2aq.

For volatile fatty acid (VFA) analysis, ileal digesta were collected on $1 \mathrm{~d}$ from 08.00 to 20.00 hours according to the same procedure described for rate of passage determinations. Fresh faeces were removed from the anus and immediately preserved with the phenol-alcohol $(50: 50, \mathrm{v} / \mathrm{v})$ solution. $\mathrm{pH}$ was determined in fresh, hourly-collected digesta samples.

\section{Analytical procedures}

Analysis of dry matter, ash, $\mathrm{N}$ and crude fat was carried out according to standard methods. 
For dry matter determinations the samples were dried in an oven at $101^{\circ}$ to constant weight. Ash was determined by incineration at $550^{\circ}$ for $4 \mathrm{~h}$. $\mathrm{N}$ content was determined using a Technicon AutoAnalyzer.

After wet digestion with $2 \cdot 0 \mathrm{M}-\mathrm{K}_{2} \mathrm{SO}_{4}$ solution in $18 \mathrm{M}-\mathrm{H}_{2} \mathrm{SO}_{4}$ and $\mathrm{Se}$ as a catalyst, the $\mathrm{N}$ was bound by hypochlorite and phenol, according to Berthelot (Association of Official Analytical Chemists, 1980). The $\mathrm{N}$ complex was measured at $630 \mathrm{~nm}$. Crude fat was determined by treating for $1 \mathrm{~h}$ with $3 \mathrm{M}-\mathrm{HCl}$ and drying for $3 \mathrm{~h}$ under vacuum at $100^{\circ}$, followed by $8 \mathrm{~h}$ extraction with hexane.

$\mathrm{N}$-free extract (NFE) was calculated as: dry matter - (ash + crude protein + crude fat + analysed sugar); so the NFE is the sum of carbohydrates + fibre originating from the basal ingredients.

Energy content was determined using an isotherm calorimeter according to a method described by the Nederlands Normalisatie Instituut (1964).

In faeces and ileal digesta lactic acid was analysed according to Boehringer (1976); VFA were analysed by gas-liquid chromatography. Samples to be analysed were prepared by treatment with a solution of $\mathrm{Ca}(\mathrm{OH})_{2}\left(3 \mathrm{~g} \mathrm{Ca}(\mathrm{OH})_{2}\right.$ per $10 \mathrm{~g}$ sample diluted to $\left.100 \mathrm{ml}\right)$, followed by filtration. The analyses were carried out using the supernatant fraction.

Sucrose, glucose, fructose, mannitol, sorbitol, GPM and GPS in the feeds, ileal digesta and in the faeces were analysed using two reversed-phase high-performance liquid chromatography (HPLC) systems: (a) column $250 \mathrm{~mm} \times 4.6 \mathrm{~mm}$ i.d. filled with $5 \mu \mathrm{m}$ Polygosil- $\mathrm{NH}_{2}$ (Mackerey-Nagel, Düren, Germany), solvent acetonitrile-water $(75: 25$, $\mathrm{v} / \mathrm{v}$ ). The following sample components can be determined with this system (in order of elution): fructose, glucose + sorbitol + mannitol (co-elution), saccharose, the sum of GPM and GPS (co-elution); (b) carbohydrate column HPX-87C (BioRad Laboratories, Richmond, Virginia, USA), solvent distilled water, column temperature $85^{\circ}$. The following sample contents can be determined with this system (in order of elution): saccharose, glucose + GPM (co-elution), GPS, fructose, mannitol, sorbitol.

For both types of HPLC analysis the elution of the components was measured with a refractive index detector (Waters R401). The quantification of each component was carried out by peak area comparison between sample chromatograms and a standard chromatogram.

The concentrations of the respective components in the standard chromatogram were known on the basis of weight of component (including crystallization water) per volume.

The detection limits of the HPLC analysis were $1 \mathrm{~g} / \mathrm{kg}$ in the feeds and $0.5 \mathrm{~g} / \mathrm{kg}$ in the wet digesta and faeces.

\section{Statistical analysis}

Separate one-way analysis of variance was used for the cannulated and non-cannulated pigs. The levels of the factor are the three different diets. The significance of differences between the treatments was tested by using the least significance difference test (Snedecor \& Cochran, 1980). All statements of significance are based on a probability of less than 0.05 .

\section{RESULTS}

In Table 3 the values for ileal sugar passage per $24 \mathrm{~h}$ were obtained by doubling the $12 \mathrm{~h}$ collection values. This procedure, applied in order to facilitate comparison with the results of the second study, was considered to be justified on the basis of the data presented in Fig. 2 , which show that after $12 \mathrm{~h}$ collection, at 20.00 hours, ileal passage of sugars was approximately zero. At the distal ileum hardly any sugars were detected when the diet 
Table 3. Intake and ileal passage of sugars in pigs fed on $200 \mathrm{~g}$ sucrose $/ \mathrm{kg}, 100 \mathrm{~g}$ sucrose plus $100 \mathrm{~g}$ isomalt $/ \mathrm{kg}$ and $200 \mathrm{~g}$ isomalt $/ \mathrm{kg}$ diets*

\begin{tabular}{|c|c|c|c|c|c|c|c|c|}
\hline \multirow[b]{2}{*}{ Diet... } & \multicolumn{3}{|c|}{ Intake $(\mathrm{g} / 24 \mathrm{~h})$} & \multicolumn{5}{|c|}{ Ileal passage $(\mathrm{g} / 24 \mathrm{~h})$} \\
\hline & $\begin{array}{c}200 \mathrm{~g} \\
\text { sucrose } / \mathrm{kg}\end{array}$ & $\begin{array}{c}100 \mathrm{~g} \\
\text { sucrose } \\
+100 \mathrm{~g} \\
\text { isomalt } / \mathrm{kg}\end{array}$ & $\begin{array}{l}200 \mathrm{~g} \\
\text { somalt } / \mathrm{kg}\end{array}$ & $\begin{array}{c}200 \mathrm{~g} \\
\text { ucrose } / \mathrm{kg}\end{array}$ & $\begin{array}{c}100 \mathrm{~g} \\
\text { sucrose } \\
+100 \mathrm{~g} \\
\text { isomalt } / \mathrm{kg}\end{array}$ & $\begin{array}{l}200 \mathrm{~g} \\
\text { somalt } / \mathrm{kg}\end{array}$ & SEM & $\mathrm{df}$ \\
\hline Sucrose & $355 \cdot 2$ & 185.6 & $20 \cdot 8$ & $<\mathrm{D}$ & $<\mathrm{D}$ & $<\mathrm{D}$ & & \\
\hline GPM.2aq & nd & $91 \cdot 2$ & $172 \cdot 8$ & nd & $39 \cdot 0^{\mathrm{a}}$ & $106 \cdot 0^{\mathrm{b}}$ & $8 \cdot 1$ & 6 \\
\hline GPS & nd & $75 \cdot 2$ & $142 \cdot 4$ & nd & $19 \cdot 7^{\mathrm{u}}$ & $61 \cdot 1^{\mathrm{b}}$ & $4 \cdot 0$ & 6 \\
\hline Glucose & $4 \cdot 0$ & $5 \cdot 6$ & $4 \cdot 8$ & $11 \cdot 4^{\mathrm{a}}$ & $16 \cdot 5^{\mathrm{ab}}$ & $20 \cdot 2^{\mathrm{b}}$ & $2 \cdot 7$ & 9 \\
\hline Fructose & $3 \cdot 2$ & $4 \cdot 8$ & 4.0 & $2 \cdot 7^{\mathrm{a}}$ & $<\mathrm{D}$ & $<\mathrm{D}$ & $0 \cdot 9$ & 3 \\
\hline Mannitol & nd & $<\mathrm{D}$ & $<\mathrm{D}$ & nd & $16 \cdot 6^{\mathrm{a}}$ & $18 \cdot 2^{a}$ & $1 \cdot 7$ & 6 \\
\hline Sorbitol & nd & $<\mathrm{D}$ & $<\mathrm{D}$ & nd & $13 \cdot 8^{\mathrm{a}}$ & $25 \cdot 5^{\mathrm{b}}$ & $1 \cdot 1$ & 6 \\
\hline $\begin{array}{l}\text { Total analysed } \\
\text { sugars }\end{array}$ & $362 \cdot 4$ & $362 \cdot 4$ & $344 \cdot 8$ & $14 \cdot 0^{\mathrm{a}}$ & $105 \cdot 5^{\mathrm{b}}$ & $230^{\cdot} 9^{\mathrm{c}}$ & $9 \cdot 9$ & 9 \\
\hline
\end{tabular}

a.b,c Values with different superscript letters within a row differed significantly $(P<0 \cdot 05)$. nd, Not determined; <D, below detection level $(0.5 \mathrm{~g} / \mathrm{kg})$.

* For details, see Tables 1 and 2.

containing $200 \mathrm{~g}$ sucrose $/ \mathrm{kg}$ was fed (Table 3). This result indicates that sucrose is almost completely digested and absorbed in the small intestine. When the diet with $100 \mathrm{~g}$ sucrose plus $100 \mathrm{~g}$ isomalt $/ \mathrm{kg}$ and the diet with $200 \mathrm{~g}$ isomalt $/ \mathrm{kg}$ were fed, considerable quantities of intact isomalt (GPM.2aq. and GPS) together with its free constituents mannitol and sorbitol passed through the distal ileum. In addition, the passage of the third component of isomalt, glucose, was slightly increased (by $5 \cdot 1 \mathrm{~g} / \mathrm{d}$ ) when the diet with $100 \mathrm{~g}$ sucrose plus $100 \mathrm{~g}$ isomalt $/ \mathrm{kg}$ was fed, and by $8.8 \mathrm{~g} / \mathrm{d}$ when the diet with $200 \mathrm{~g}$ isomalt $/ \mathrm{kg}$ was fed. The passage of fructose was not increased when these diets were fed. This observation indicates that this additional glucose passage originates most probably from isomalt and not from the basal ingredients maize and soya-bean oil-meal. No sugars were excreted in the faeces with any of the treatments, indicating that the sugars passing through the distal ileum were completely broken down in the large intestine.

The data for ileal passage of sugars show that by doubling the intake of isomalt the passage of intact isomalt (GPM.2aq. + GPS) was nearly tripled. The passage rate of free mannitol was hardly increased, but sorbitol passage was nearly doubled by doubling intake of isomalt. From the data for isomalt intake and ileal passage of sugars it was calculated that from the $100 \mathrm{~g}$ isomalt $/ \mathrm{kg}$ dose approximately 0.54 passed the distal ileum and from the $200 \mathrm{~g} / \mathrm{kg}$ dose the value was approximately 0.70 . This means that approximately $0 \cdot 43$ and 0.30 of the administered doses of isomalt respectively were digested in the small intestine. These calculations are based on the ileal passage of GPM.2aq + GPS + mannitol + sorbitol + additional glucose. The digestibility values mentioned will slightly overestimate the real situation because sugar concentrations in the ileal chyme below the detection limits as well as small amounts of sugar passing the ileum after the $12 \mathrm{~h}$ collection all result in low values for ileal passage.

Fig. 1 shows that during a period of $2-3 \mathrm{~h}$ after feeding the passage rate of wet ileal digesta in both isomalt groups was drastically increased above the level of the sucrose treatment. Especially when the diet with $200 \mathrm{~g}$ isomalt $/ \mathrm{kg}$ was fed, a transient, extremely high passage rate was observed. The amounts of wet digesta $(\mathrm{g})$ that daily passed the distal 


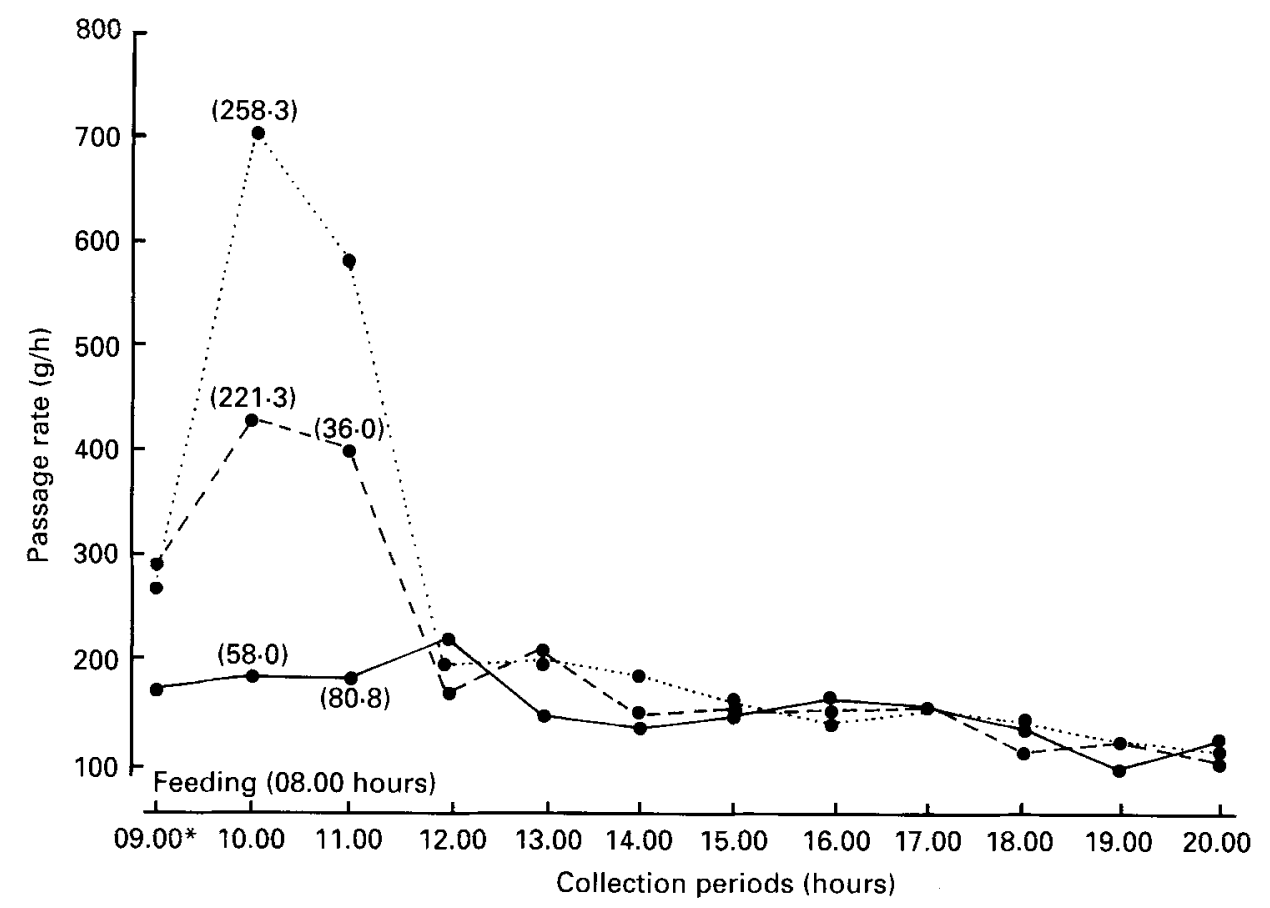

Fig. 1. Passage rate $(\mathrm{g} / \mathrm{h})$ of wet ileal digesta of pigs fed on $200 \mathrm{~g}$ sucrose $/ \mathrm{kg} \operatorname{diet}(-), 100 \mathrm{~g}$ sucrose plus $100 \mathrm{~g}$ isomalt $/ \mathrm{kg}$ diet (---) and $200 \mathrm{~g}$ isomalt $/ \mathrm{kg}$ diet $(\cdots)$. Each curve is the mean of twenty curves, four animals $\times 5 \mathrm{~d}$, with standard deviations shown in parentheses. ${ }^{*}$ Each collection period comprised the preceding 60 min. For details of diets, see Tables 1 and 2.

ileum were on an average: $200 \mathrm{~g}$ sucrose $/ \mathrm{kg}$ group $3586,100 \mathrm{~g}$ sucrose plus $100 \mathrm{~g}$ isomalt $/ \mathrm{kg}$ group $4846,200 \mathrm{~g}$ isomalt $/ \mathrm{kg}$ group 5923. The dry matter contents of ileal digesta were on an average 103,97 and $101 \mathrm{~g} / \mathrm{kg}$ respectively.

Fig. 2 shows that this high digesta flow coincided with a high passage rate of intact isomalt (GPM.2aq + GPS). This observation indicates that the increased digesta flow was related to the passage of osmotically active isomalt components. The isomalt components in the digesta will cause an inflow of water into the intestinal lumen in order to maintain osmotic equilibrium between blood and lumen content. As a result the amount of wet digesta will increase.

Table 4 shows that during, as well as after, the period that the passage rate was at its maximum the ileal digesta were isotonic (osmolality of blood approximately $320 \mathrm{mosmol} / \mathrm{l}$ ).

Table 5 shows the contents of lactic acid and VFA in ileal digesta and faeces. The major proportion of the organic acids in ileal digesta was present as lactic acid; in faeces the major proportion was VFA. The mean contents of lactic acid in the ileal digesta of the pigs fed on the $200 \mathrm{~g}$ sucrose $/ \mathrm{kg}$ diet were higher than those in both isomalt groups; however, the variability between animals in the former group was very considerable. So, in conclusion, no indications were found for marked differences in fermentative activity in the chyme at the end of the ileum between the sucrose and both isomalt groups. In a group of pigs in another study fed on a diet with the same basal composition but without sugar and containing the anti-microbial agents copper sulphate and an antibiotic, the contents of lactic acid and VFA in the ileal chyme were at about the same level $(2.42 \mathrm{~g} \mathrm{VFA}$ and $7.61 \mathrm{~g}$ total organic acids $/ \mathrm{kg}$ wet chyme) as that in the pigs fed on the different sugars. In faeces, also, no differences in contents of organic acids were found between the treatments. The 


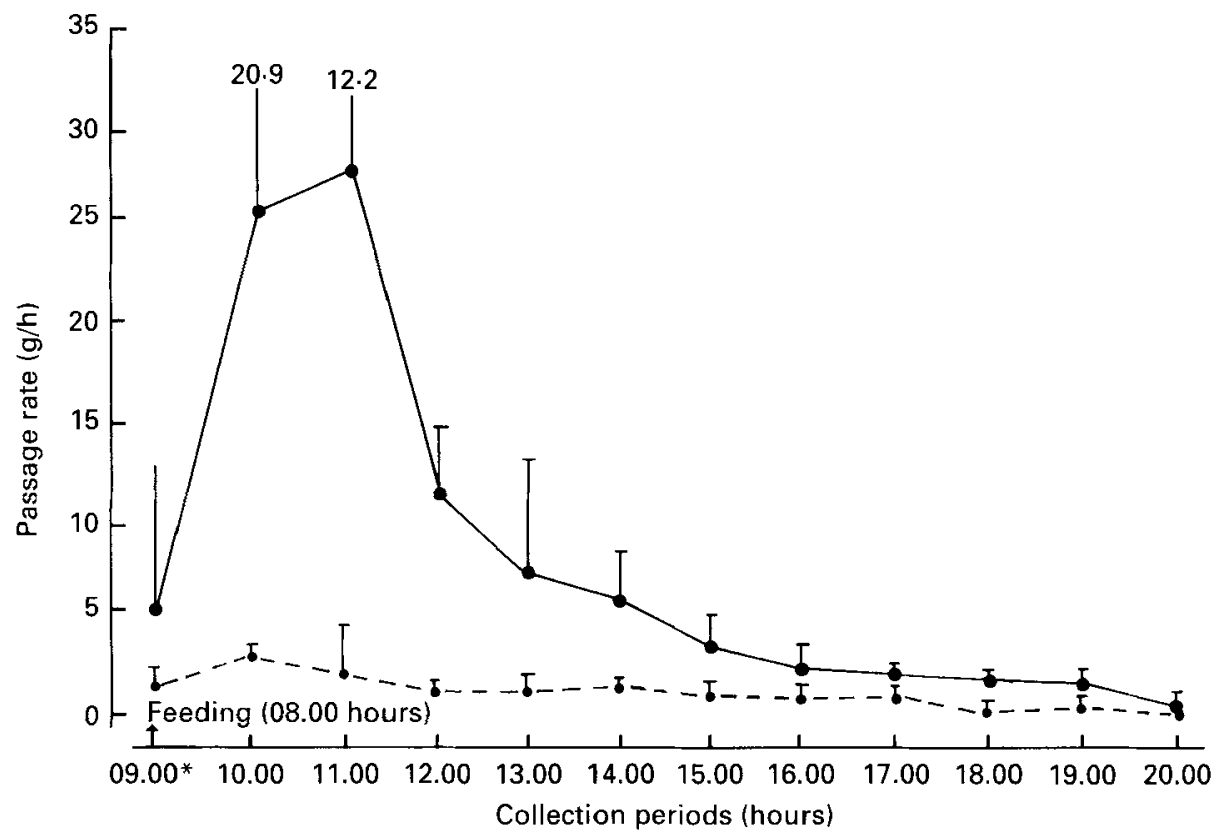

Fig. 2. Passage rate $(\mathrm{g} / \mathrm{h})$ of intact isomalt ( $\alpha$-D-glucopyranosyl-1,1-D-mannitol plus $\alpha$-D-glucopyranosyl-1,6-Dsorbitol) (- ) and free mannitol plus sorbitol (- - ) at the distal ilcum of pigs fed on $200 \mathrm{~g}$ isomalt $/ \mathrm{kg}$ diet. Each curve is the mean of eight curves; four animals $\times 2 \mathrm{~d}$, with standard deviations represented by vertical bars. *Each collection period comprised the preceding $60 \mathrm{~min}$. For details of diets, see Tables I and 2.

Table 4. Concentrations of osmotically active components ( $\mathrm{mOsmol} / \mathrm{kg}$ ) in pooled samples of wet ileal digesta from pigs fed $200 \mathrm{~g}$ sucrose $/ \mathrm{kg}$ diet and $200 \mathrm{~g}$ isomalt $/ \mathrm{kg}$ diets*

\begin{tabular}{ccc}
\hline & Sucrose diet & Isomalt diet \\
\hline $\begin{array}{c}\text { Determined during the peak in passage rate } \\
\text { of digesta }(10 \ldots 12 \mathrm{~h}) \\
\begin{array}{c}\text { Determined after the peak in passage rate } \\
\text { of digesta }(14-16 \mathrm{~h})\end{array}\end{array}$ & 340 & 317 \\
\hline
\end{tabular}

* For details of diets, see Tables 1 and 2.

latter result indicates that the organic acids formed in the fermentation process of isomalt in the large intestine are completely broken down or absorbed.

The average values for the $\mathrm{pH}$ of the ileal chyme measured over a period of $12 \mathrm{~h}$ (08.00-20.00 hours) were: $200 \mathrm{~g}$ sucrose $/ \mathrm{kg}$ diet $6.9,100 \mathrm{~g}$ sucrose plus $100 \mathrm{~g}$ isomalt $/ \mathrm{kg}$ diet $7 \cdot 2,200 \mathrm{~g}$ isomalt $/ \mathrm{kg}$ diet 6.8 ; the difference between the first two groups was significant $(P<0.05)$. The $\mathrm{pH}$ in faeces hardly differed between the treatments.

Table 6 shows the ileal and faecal digestibilities of the diets. The ileal digestibility coefficients of dry matter, organic matter and energy were significantly lower for the isomalt diets than for the sucrose diet, and the $200 \mathrm{~g}$ isomalt $/ \mathrm{kg}$ diet was significantly lower than the diet with $100 \mathrm{~g}$ sucrose plus $100 \mathrm{~g}$ isomalt $/ \mathrm{kg}$. Isomalt contributed to dietary dry matter, organic matter and energy, but had a low ileal digestibility $(0.43$ and 0.30 for $100 \mathrm{~g}$ and $200 \mathrm{~g}$ isomalt $/ \mathrm{kg}$ diets respectively). The ileal digestibility of NFE, originating from maize and soya-bean meal (see pp. 457-458), did not differ between the diets $(P>0.05)$. 
Table 5. Mean concentrations ( $\mathrm{g} / \mathrm{kg}$ wet ileal digesta or wet faeces) of lactic acid and volatile fatty acids (VFA) in pigs fed on $200 \mathrm{~g}$ sucrose $/ \mathrm{kg}, 100 \mathrm{~g}$ sucrose plus $100 \mathrm{~g}$ isomalt $/ \mathrm{kg}$ and $200 \mathrm{~g}$ isomalt $/ \mathrm{kg}$ diets

\begin{tabular}{|c|c|c|c|c|c|c|c|c|}
\hline & \multicolumn{4}{|c|}{ Ileal digesta } & \multicolumn{4}{|c|}{ Faeces } \\
\hline & Sucrose & $\begin{array}{l}\text { Sucrose } \\
+ \text { isomalt }\end{array}$ & Isomalt & $\begin{array}{l}\text { SEM } \\
\text { (df 9) }\end{array}$ & Sucrose & $\begin{array}{l}\text { Sucrose } \\
+ \text { isomalt }\end{array}$ & Isomalt & $\begin{array}{r}\text { SEM } \\
(\mathrm{df} 9)\end{array}$ \\
\hline L-lactic acid & $4 \cdot 67^{2}$ & $2 \cdot 20^{4}$ & $2 \cdot 36^{\mathrm{a}}$ & 0.97 & - & - & - & - \\
\hline D-lactic acid & $2 \cdot 21^{2}$ & $1 \cdot 57^{a}$ & $1 \cdot 96^{\text {t }}$ & 0.48 & - & - & - & - \\
\hline DL-lactic acid & $6.88^{a}$ & $3 \cdot 77^{\mathrm{a}}$ & $4 \cdot 32^{a}$ & 1.37 & $0.29+$ & $0.17 \dagger$ & $0.01+$ & - \\
\hline Acetic acid & $1 \cdot 60^{\mathrm{a}}$ & $1.45^{\mathrm{ah}}$ & $1 \cdot 11^{\mathrm{b}}$ & 0.13 & $6 \cdot 20^{a}$ & $5 \cdot 74^{\mathrm{a}}$ & $5 \cdot 45^{a}$ & 0.37 \\
\hline Propionic acid & $0.26^{a}$ & $0.25^{\mathrm{a}}$ & $0 \cdot 26^{a}$ & $0 \cdot 06$ & $2 \cdot 12^{a}$ & $2 \cdot 36^{\mathrm{a}}$ & $2 \cdot 73^{\mathrm{d}}$ & $0 \cdot 33$ \\
\hline Isobutyric acid & $<0.01$ & - & - & - & $0.21^{\mathrm{a}}$ & $0 \cdot 27^{\mathrm{a}}$ & $0 \cdot 16^{\mathrm{a}}$ & 0.05 \\
\hline Butyric acid & $0.08^{\mathrm{a}}$ & $0.05^{a}$ & $0 \cdot 07^{\mathrm{a}}$ & $0-03$ & $1.75^{\mathrm{a}}$ & $1.66^{\mathrm{a}}$ & $1 \cdot 11^{\mathrm{a}}$ & $0 \cdot 25$ \\
\hline Isovaleric acid & 0.02 & $<0.01$ & $<0.01$ & & $0 \cdot 33^{\mathrm{a}}$ & $0 \cdot 48^{a}$ & $0.26^{\mathrm{a}}$ & 0.07 \\
\hline Vaieric acid & - & 0.08 & $<0.01$ & & $0.59^{\mathrm{a}}$ & $0.77^{a b}$ & $1.09^{\mathrm{b}}$ & $0 \cdot 11$ \\
\hline Total VFA & 1.96 & $1.83^{a}$ & $1 \cdot 44^{\mathrm{a}}$ & $0 \cdot 20$ & $11 \cdot 20^{\mathrm{a}}$ & $11 \cdot 28^{\mathrm{a}}$ & $10 \cdot 80^{\mathrm{a}}$ & 1.01 \\
\hline $\begin{array}{l}\text { Total organic } \\
\text { acids }\end{array}$ & $8 \cdot 84^{a}$ & $5 \cdot 60^{a}$ & $5 \cdot 76^{a}$ & 1.33 & $11 \cdot 49$ & $11 \cdot 46$ & $10 \cdot 81$ & - \\
\hline
\end{tabular}

a.b Values with different superscript letters within a row were significantly different $(P<0.05)$.

* For details of diets, see Tables 1 and 2.

$\dagger$ Measured in pooled samples.

Table 6. Apparent ileal and faecal digestibility coefficients in pigs fed on $200 \mathrm{~g}$ sucrose $/ \mathrm{kg}$, $100 \mathrm{~g}$ sucrose plus $100 \mathrm{~g}$ isomalt $/ \mathrm{kg}$ and $200 \mathrm{~g}$ isomalt $/ \mathrm{kg}$ diets ${ }^{*}$

\begin{tabular}{|c|c|c|c|c|c|c|c|c|}
\hline & \multicolumn{4}{|c|}{ Ileal digestibility } & \multicolumn{4}{|c|}{ Faecal digestibility } \\
\hline & Sucrose & $\begin{array}{l}\text { Sucrose } \\
+ \text { isomalt }\end{array}$ & Isomalt & SEM & Sucrose & $\begin{array}{l}\text { Sucrose } \\
+ \text { isomalt }\end{array}$ & Isomalt & SEM \\
\hline Dry matter & $0.748^{a}$ & $0.682^{\mathrm{h}}$ & $0.590^{\circ}$ & $0 \cdot 013$ & $0.888^{a}$ & $0.877^{\mathrm{ab}}$ & $0.853^{\mathrm{b}}$ & 0.009 \\
\hline Organic matter & $0.774^{2}$ & $0 \cdot 707^{\mathrm{h}}$ & $0.610^{\circ}$ & 0.012 & $0.906^{a}$ & $0.895^{\mathrm{a}}$ & $0.871^{\circ}$ & 0.009 \\
\hline $\begin{array}{l}\text { Crude protein } \\
(\mathrm{N} \times 6.25)\end{array}$ & 0.719 & 0.713 & $0 \cdot 651$ & 0.023 & $0.824^{a}$ & $0.795^{\mathrm{ab}}$ & $0.725^{\mathrm{b}}$ & 0.022 \\
\hline Crude fat & 0.493 & 0.544 & 0.476 & 0.027 & 0.522 & 0.554 & 0.535 & 0.010 \\
\hline $\mathrm{N}$-free extract $\dagger$ & 0.719 & 0.716 & 0.733 & 0.013 & $0.908^{\mathrm{a}}$ & $0.897^{\mathrm{ab}}$ & $0.873^{\mathrm{b}}$ & 0.010 \\
\hline Gross energy & $0.760^{\mathrm{a}}$ & $0.696^{\mathrm{b}}$ & $0 \cdot 604$ & 0.013 & $0.880^{a}$ & $0.870^{\mathrm{ab}}$ & $0.841^{\mathrm{b}}$ & 0.010 \\
\hline
\end{tabular}

a,b.e Values with different superscript letters within a row of the ileal or faecal digestibility coefficients were significantly different $(P<0 \cdot 05)$.

* For details of diets, see Tables 1 and 2.

$\dagger$ Excluding the test sugars (see p. 458).

There was a tendency for a lower ileal digestibility of protein with the $200 \mathrm{~g}$ isomalt $/ \mathrm{kg}$ diet, but the differences for the other groups were not significant. The faecal digestibility of organic matter, protein, NFE and energy of the $200 \mathrm{~g}$ isomalt $/ \mathrm{kg}$ diet was significantly reduced $(P<0.05)$. A decrease in faecal protein digestibility was also observed with the sucrose + isomalt diet, but here the difference from the $200 \mathrm{~g}$ sucrose $/ \mathrm{kg}$ diet was not significant. It can be calculated that the lower $\mathrm{N}$ digestibility could account for about half the decrease in energy digestibility and that the lower NFE digestibility could account for the remainder. 
Table 7. Nitrogen and energy excretion with faeces and urine, metabolizable energy and nitrogen balance in non-cannulated pigs fed on $200 \mathrm{~g}$ sucrose $/ \mathrm{kg}, 100 \mathrm{~g}$ sucrose plus $100 \mathrm{~g}$ isomalt $/ \mathrm{kg}$ and $200 \mathrm{~g}$ isomalt $/ \mathrm{kg}$ diets*

\begin{tabular}{|c|c|c|c|c|c|c|c|}
\hline & \multicolumn{2}{|c|}{ Sucrose } & \multicolumn{2}{|c|}{ Sucrose + isomalt } & \multicolumn{2}{|c|}{ Isomalt } & \multirow[b]{2}{*}{ SEM } \\
\hline & $\mathrm{g} / 24 \mathrm{~h}$ & $\%$ of intake & $\mathrm{g} / 24 \mathrm{~h}$ & $\%$ of intake & $\mathrm{g} / 24 \mathrm{~h}$ & $\%$ of intake & \\
\hline $\mathrm{N}$ intake & $32 \cdot 2$ & 100 & $33 \cdot 4$ & 100 & $32 \cdot 6$ & 100 & - \\
\hline $\mathrm{N}$ excretion with faeces & $5 \cdot 6^{\mathrm{a}}$ & $17 \cdot 6$ & $6 \cdot 8^{\mathrm{ab}}$ & $20 \cdot 5$ & $9 \cdot 0^{\mathrm{bc}}$ & $27 \cdot 6$ & 0.7 \\
\hline $\mathrm{N}$ excretion with urine & 11.8 & 36.5 & $11 \cdot 5$ & $34 \cdot 5$ & $10 \cdot 6$ & $32 \cdot 3$ & 0.6 \\
\hline \multirow[t]{3}{*}{$\mathrm{N}$ balance } & $14 \cdot 8$ & $46 \cdot 0$ & $15 \cdot 0$ & $45 \cdot 0$ & $13 \cdot 1$ & $40 \cdot 1$ & 0.7 \\
\hline & \multicolumn{2}{|c|}{ Sucrose } & \multicolumn{2}{|c|}{ Sucrose + isomalt } & \multicolumn{2}{|c|}{ Isomalt } & \\
\hline & $\mathrm{MJ} / 24 \mathrm{~h}$ & $\%$ of intake & $\mathrm{MJ} / 24 \mathrm{~h}$ & $\%$ of intake & $\mathrm{MJ} / 24 \mathrm{~h}$ & $\%$ of intake & SEM \\
\hline Energy intake & $26 \cdot 17$ & 100 & $26 \cdot 29$ & 100 & $26 \cdot 23$ & 100 & - \\
\hline $\begin{array}{l}\text { Energy excretion with } \\
\text { faeces }\end{array}$ & $3 \cdot 14^{4}$ & $12 \cdot 0$ & $3.42^{\mathrm{n}}$ & $13 \cdot 0$ & $4 \cdot 17^{\mathrm{c}}$ & $15 \cdot 9$ & 0.05 \\
\hline $\begin{array}{l}\text { Energy excretion with } \\
\text { urine }\end{array}$ & 0.65 & $2 \cdot 5$ & 0.69 & $2 \cdot 6$ & 0.63 & $2 \cdot 4$ & 0.03 \\
\hline Metabolizable energy $\dagger$ & $22 \cdot 38^{\mathrm{a}}$ & $85 \cdot 5$ & $22 \cdot 18^{b}$ & $84 \cdot 4$ & $21.43^{\mathrm{e}}$ & $81 \cdot 7$ & 0.05 \\
\hline $\begin{array}{l}\text { Metabolizable energy } \\
(\mathrm{MJ} / \mathrm{kg} \text { feed })\end{array}$ & $13 \cdot 98^{\mathrm{a}}$ & - & $13 \cdot 86^{\mathrm{b}}$ & - & $13 \cdot 39^{\mathrm{c}}$ & - & $0 \cdot 03$ \\
\hline
\end{tabular}

a.b.c Values with different superscript letters within a row were significantly different $(P<0 \cdot 05)$.

* For details of diets, see Tables 1 and 2.

$\dagger$ Not corrected for $\mathrm{N}$ equilibrium.

Table 7 shows values for $\mathrm{N}$ intake, $\mathrm{N}$ excretion in faeces and urine and $\mathrm{N}$ balance. The results indicate that the significantly higher $(P<0.05)$ excretion of $\mathrm{N}$ with faeces in the $200 \mathrm{~g}$ isomalt $/ \mathrm{kg}$ diet is partly, though not significantly, compensated by a lower excretion of $\mathrm{N}$ in urine. From Table 7 it is clear that the higher faecal excretion of energy in the diets with isomalt is not compensated by a lower urinary energy excretion. As a result metabolizable energy for these diets was significantly lower than that for the other treatments.

\section{DISCUSSION}

In a study by Zinner et al. (1985) the findings suggest an ileal passage of isomalt of $0 \cdot 71-0 \cdot 81$ of intake with dietary levels of 125 and $150 \mathrm{~g}$ isomalt $/ \mathrm{kg}$. However, because of important differences in experimental design compared with the present experiment, especially with regard to the age of the test animals, cannulation technique and type of diet, a discussion of the different results is not meaningful.

Our findings do not lead to a reliable estimate of the extent to which isomalt is fermented in the small intestine. From the literature (Jensen, 1988; Longland et al. 1988) it is known that certain non-starch polysaccharide fractions are fermented to a substantial degree in the small intestine of pigs. In our study considerable quantities of organic acids (average values $57-86 \mathrm{~g} / \mathrm{kg}$ chyme dry matter) were found in the ileal chyme (Table 5), but the levels in the isomalt groups were not higher than those in the sucrose group and not significantly different from that of a group fed on the basal diet without sugars. The observation that organic acid content in ileal chyme of isomalt-fed pigs is not increased does not necessarily mean that bacterial breakdown of this sugar does not occur because absorption of VFA is very rapid (Longland et al. 1988). 
The observation that apparent ileal digestibility of energy is depressed when increasing amounts of isomalt are included in the diet (Table 6) can be explained by the low ileal digestibility of isomalt $(0.43$ and 0.30 with 100 and $200 \mathrm{~g} / \mathrm{kg}$ inclusion levels respectively). However, when the digestibility coefficients of isomalt are calculated from the ileal energy digestibility values (Table 6), assuming a constant energy digestibility coefficient for the basal components, then the isomalt digestibilities are lower, i.e. 0.35 and 0.22 for the 100 and $200 \mathrm{~g} / \mathrm{kg}$ dietary inclusion levels respectively. This is an indication that the assumption that the digestibility of the basal components is constant is not justified. The increased chyme flow during the period $2-3 \mathrm{~h}$ after feeding in the isomalt groups (Fig. 1) seems to carry along some components from the basal diet. The finding that ileal protein digestibility in the $200 \mathrm{~g}$ isomalt $/ \mathrm{kg}$ group is depressed, though not significantly, points also to a secondary effect of isomalt on the ileal digestion of the basal diet. This question together with the possible interaction between digestibility and dose of isomalt will be discussed in more detail in the following paper (van Weerden \& Huisman, 1993), in which the findings of the study with dietary isomalt levels of 50 and $100 \mathrm{~g} / \mathrm{kg}$ are described.

Whereas the faecal digestibility of isomalt measured directly via analysis of the faeces is 1.00 , the indirect calculation via faecal energy digestibility and assuming constant basal diet digestibility leads to a faecal isomalt digestibility of 0.898 for the $100 \mathrm{~g}$ isomalt $/ \mathrm{kg}$ dose and 0.805 for the $200 \mathrm{~g}$ isomalt $/ \mathrm{kg}$ dose. This indicates that the faecal digestibility of the basal diet is influenced by the presence of isomalt in the diet. This is confirmed by values in Table 6 of reduced faecal organic matter and protein digestibility in the isomalt groups. A decrease in faecal energy and protein digestibilities in diets with isomalt was also reported by Kirchgessner \& Müller (1983) in sows fed on a diet with $300 \mathrm{~g}$ isomalt $/ \mathrm{kg}$, and by Staudacher \& Kirchgessner (1984) in young rats fed on a diet with $300 \mathrm{~g}$ isomalt $/ \mathrm{kg}$. A decreased faecal protein digestibility when feeding pigs on diets containing components which are fermented in the large intestine is a general phenomenon, explained by an increase in bacterial protein voided with the faeces (Zebrowska, 1982).

The increased faecal $\mathrm{N}$ excretion in the $100 \mathrm{~g}$ isomalt $/ \mathrm{kg}$ group was not compensated by a lower urinary $\mathrm{N}$ excretion, and $\mathrm{N}$ balance was almost equal to $\mathrm{N}$ balance in the sucrose group (Table 7). In the $200 \mathrm{~g}$ isomalt $/ \mathrm{kg}$ group a tendency to a lower urinary $\mathrm{N}$ excretion was observed, but the differences with the sucrose and the $100 \mathrm{~g}$ isomalt $/ \mathrm{kg}$ group were not significant. These findings are in agreement with the results of studies of Kirchgessner \& Müller (1983) with sows fed on $300 \mathrm{~g}$ isomalt $/ \mathrm{kg}$, and studies of Staudacher \& Kirchgessner (1984) with rats fed on $300 \mathrm{~g}$ isomalt $/ \mathrm{kg}$.

Values for variables of energy metabolism measured in the present study (Table 7) are similar to those of $\mathrm{N}$ metabolism (an increase in faecal energy excretion was not compensated by a decrease in urinary energy excretion), the differences in metabolizable energy among treatments being significant. The finding that urinary energy excretion is not increased in the 100 and $200 \mathrm{~g}$ isomalt $/ \mathrm{kg}$ groups is interesting as in man it is generally assumed that absorbed mannitol is utilized only to a small extent in the body and the main part is excreted via the urine (Food and Agriculture Organization/World Health Organization, 1980; Wang \& Van Eys, 1981). However, as discussed by the Committee on Polyalcohols of The Netherlands' Nutrition Council (1987), this phenomenon was observed when large doses of mannitol were administered; for more practical, small doses the Committee assumed, rather arbitrarily, that about half the absorbed amount of mannitol will be excreted in the urine. In our study with pigs it was calculated (Table 3 ) that small intestinal absorption of mannitol from isomalt in the $200 \mathrm{~g} / \mathrm{kg}$ group was $12 \cdot 7 \mathrm{~g} / 24 \mathrm{~h}$. When this amount should have been excreted with urine, urinary energy excretion should have been increased with approximately $0.20 \mathrm{MJ} / 24 \mathrm{~h}$. Unfortunately, mannitol analyses have not been carried out in urine, but the fact that energy excretion was not increased in 
both isomalt groups is strong evidence that mannitol excretion via the urine was not taking place to any appreciable extent in our study.

In conclusion it can be stated that, when basing the calculation on ileal sugar analyses, in the present study 0.43 and 0.30 of dietary doses of 100 and $200 \mathrm{~g}$ isomalt $/ \mathrm{kg}$ were digested in the small intestine. When basing the calculation on ileal energy digestibility, the isomalt digestibilities were 0.35 and 0.22 respectively. The remainder was fermented by bacteria in the large intestine, resulting in an increased faecal excretion of $\mathrm{N}$ and energy. When considering the useful energy of isomalt the losses of energy coupled with this fermentation process should be taken into account.

\section{REFERENCES}

Association of Official Analytical Chemists (1980). Official Methods of Analysis. 13th ed. Washington, DC: Association of Official Analytical Chemists.

Boehringer (1976). Methods of enzymatic food analysis. Mannheim, Germany: Boehringer.

Close, W. H., Longland, A. C. \& Low, A. G. (1989). Energy metabolism studies on pigs fed diets containing sugar-beet pulp. Animal Production 48, 625-626.

Close, W. H., Pettigrew, J. E., Sharpe, C. E., Keal, H. D. \& Hartland, J. I. (1990). The metabolic effects of feeding diets containing sugar-beet pulp to sows. Animal Production 50, 559-560.

Easter, R. A. \& Tanksley, T. D. (1973). A technique for re-entrant ileocecal cannulation of swine. Journal of Animal Science 36, 1099-1103.

Food and Agriculture Organization/World Health Organization (1980). Carbohydrates in Human Nutrition. FAO Food and Nutrition Paper. Rome: FAO.

Graham, H. \& Aman, P. (1987). The pig as a model in dietary fibre digestion studies. Scandinavian Journal of Gastroenterology 22, Suppl. 129, 55-61.

Grupp, V. \& Siebert, G. (1978). Metabolism of hydrogenated palatinose, an equimolar mixture of $\alpha$-Dglucopyranisido-1,6-sorbitol and $\alpha$-1)-glucopyranisido-1,6-mannitol. Research in Experimental Medicine 173, 261-278

Heymann, H. (1991). Isolierung und Charakterisierung von Di- und Oligosaccharidasen aus Dünndarmmucosa (Isolation and characterization of $\mathrm{di}$ - and oligosaccharides from small intestine mucosa). Dissertation, University of Hannover.

Jensen, B. B. (1988). Effect of diet composition and Virginiamyoen on microbial activity in the digestive tract of pigs. Proceedings of the 4th International Seminar on Digestive Physiology in the Pig, pp. 392-400. Jablonna: Poland Academy of Sciences.

Just, A., Fernandez, J. A. \& Jorgensen, H. (1983). The net energy value of diets for growth in pigs in relation to the fermentative processes in the digestive tract and the site of absorption of the nutrients. Livestock Production Science 10, 171-186.

Kirchgessner, M. \& Müller, H. L. (1983). Palatinit ${ }^{R}$ Verdaulichkeit, Umsetzbarkeit und Verwertung der Energie im Modellversuch an Sauen (Palatinit ${ }^{R}$, digestibility, metabolisability and availability of the energy in a model experiment with sows), Zeitschrift für Ernährungswissenschaft 22, 234-240.

Longland, A. C., Low, A. G. \& Close, W. H. (1988). Contribution of carbohydrate fermentation to energy balance in pigs. Procecdings of the 4th International Seminar on Digestive Physiology in the Pig, pp. $108-120$. Jablonna: Poland Academy of Sciences.

Musch, K., Siebert, G., Schiweck, H. \& Steinle, G. (1973). Ernährungsphysiologische Untersuchungen mit Isomaltit an der Ratte (Nutritional/physiological studies with Isomalt in rats). Zeitschrift für Ernährungswissenschaft Suppl. 15, 316.

Nederlands Normalisatie Instituut (1964). Prescription NEN 935-11. The Hague, Netherlands: Nederlands Normalisatie Instituut.

Nilsson, U. \& Jägerstad, M. (1987). Hydrolysis of lactitol, maltitol and Palatinit ${ }^{\mathrm{R}}$ by human intestinal biopsies. British Journal of Nutrition 58, 199-206.

Nutrition Council (1987). The Energy Value of Sugar Alcohols. The Hague: Voedingsraad.

Schiweck, H. (1980). Palatinit ${ }^{P}$ Herstellung, technologische Eigenschaften und Analytik palatinithaltiger Lebensmittel (Palatinit", production, technological properties and analytical methods of foodstuffs containing Palatinit). Alimenta 19, 5-16.

Snedecor, G. W. \& Cochran, W. G. (1980). Statistical Methods, 7th ed. Ames, Iowa: The Iowa State Unjversity Press.

Staudacher, W. \& Kirchgessner, M. (1984). Protein- und Fettansatz sowie Energieverwertung bei Verfütterung von Palatinit ${ }^{k}$ an wachsende Ratten (Protein and fat deposition and energy utilisation when feeding Palatinit ${ }^{R}$ to growing rats). Zeitschrift für Tierphysiologie, Tierernährung and Futtermittelkunde 52, 272-283.

van Es, A. J. H. (1982). Energy metabolism in pigs. Proceedings of the 9th Symposium on Energy Metabolism, Lillehammer, pp. 1-7. Norway: European Association for Animal Production. 
van Es, A. J. H. (1987). Energy utilization of low digestibility carbohydrates. In Low Digestibility Carbohydrates; Proceedings of the 1986 TNO-CIVO Workshop, pp. 121-127 [D. C. Leegwater, V. J. Feron and R. J. J. Hermus, editors]. Wageningen: Pudoc.

van Weerden, E. J. \& Huisman, J. (1993). The digestion process of the sugar alcohol isomalt in the intestinal tract of the pig 2. Studies with administration of isomalt as a sweet. British Journal of Nutrition 69, 467-479.

Wang, Y. M. \& van Eys, J. (1981). Nutritional significance of fructose and sugar alcohols. Annual Review of Nutrition 1, 437-475.

Zebrowska, T. (1982). Nitrogen digestion in the large intestine. In Digestive Physiology in the Pig. 2e Séminaire international Jouy-en-Josas-Versailles, France, pp. 225-236 [J. P. Laplace, T. Corring and A. Rerat, editors] Jouy-en-Josas : INRA.

Zinner, P. M., Kirchgessner, M., Ascherl, R. \& Erhardt, W. (1985). Zur präcäcalen Absorption von Palatinit beim ausgewachsenen Schwein (Precaecal absorption of Palatinit in adult swine). Zeitschrift für Tierphysiologie, Tierernährung und Futtermittelkunde 53, 79-83. 